\title{
Effect of roe buck removal on marking intensity
}

\author{
Agneta JOHANSSON
}

\begin{abstract}
Johansson A. 2000. Effect of roe buck removal on marking intensity. Acta Theriologica 45: $123-128$.

An experiment was performed in a roe deer Capreolus capreolus (Linnaeus, 1758) population to assess the effect of a large-scale removal of adult males on the intensity of marking behaviour. Rubs and scrapes were censused in two 150-ha areas, one experimental and one control, in southeastern Sweden in May 1991 and 1992. In the experimental area, 14 males (50\% of total number, $11 \geq 3 \mathrm{yrs}$ ) were culled during mid-August 1991. Removed males were replaced by the following season. Despite this, the number of scrapes, but not the number of rubs, was significantly fewer in the experimental area in May 1992 as compared to the control. This reduction could be due to a late arrival of replacement males, which would explain why the reduction involved scrapes rather than rubs, as scraping activity starts several weeks before rubbing. To cull adult males between territorial seasons is thus not an effective way to reduce rubbing intensity, and hence damages, on young forest plantations.
\end{abstract}

Department of Zoology, Stockholm University, S-106 91 Stockholm, Sweden

Key words: Capreolus capreolus, marking, removal experiment

\section{Introduction}

Mature male roe deer Capreolus capreolus (Linnaeus, 1758) are territorial from early spring (March-April) until the rut is over in late August-early September (eg Bramley 1970, Strandgaard 1972, Kurt 1991). Roe bucks become physiologically mature as yearlings, but do not usually defend territories until 3 to 4 years, depending on the demography of the population (Bramley 1970, Strandgaard 1972, Kurt 1991). During the territorial season, males perform two types of marking behaviour: pawing the ground with the front hooves, termed scraping, and rubbing antlers and forehead against stems of trees and bushes (termed fraying/rubbing). Both types leave conspicious marks, and probably also facilitate olfactory communication as roe deer possess skin glands both on the head and between the digits of the hooves (Raesfeld et al. 1985). Scraping activity commences in March at the latest, and peaks in April (Johansson et al. 1995) or May (Davies and Davies 1968, Sempéré et al. 1980). Rubbing starts later, by the beginning of April, and increases sharply during the second half of this month (Johansson et al. 1995). Both scraping and rubbing continue throughout the territorial season and cease by September, after the breeding season (Sempéré et al. 1980, Johansson et al. 1995). The function 
of the two types of markings is disputed, and suggestions include territorial marking, display, self-orientation, and communication to males and females (Strandgaard 1972, Sempéré et al. 1980, Kurt 1991, Johansson et al. 1995).

An aspect of great economic importance is the considerable damage that might result from frequent rubbing, especially in young plantations. A thorough understanding of the function underlying marking behaviour is critical if we want to minimize damage. In an attempt to gain such an understanding, Cumming (1966, 1974) compared different shooting regimes during one territorial season and observed substantially more rubbed trees in areas where territorial males were removed and non-territorials were left than vice versa.

The aim of the present study was to investigate how marking intensity was affected by a large-scale removal of primarily adult ( $\geq 3$ yrs old) male roe deer between two territorial seasons. In May, for two consecutive years, I compared the number of rubs and scrapes in an experimental area in which culling was performed at the end of the first year's territorial season, with a nearby control area with no shooting.

\section{Study area and methods}

The study was carried out at Bogesund $\left(59^{\circ} 24^{\prime} \mathrm{N}, 18^{\circ} 12^{\prime} \mathrm{E}\right)$ in southeastern Sweden in 1991 and 1992. The study area is 2500 ha and is dominated by commercial coniferous and mixed forests (ca $70 \%$ ), the rest being agricultural land. Dominant tree species are Scots pine Pinus sylvestris, Norway spruce Picea abies, birch Betula spp., and oak Quercus robur. The climate is characterized by warm and relatively dry summers and moderate winters with snow normally occurring during December-March. However, both winters preceding my censuses were unusually mild with little or no snow. The population of roe deer is free-ranging and was protected from hunting from 1988. Population densities were $31 \mathrm{deer} / \mathrm{km}^{2}$ in 1991 and $28 \mathrm{deer} / \mathrm{km}^{2}$ in 1992 (Wahlström and Liberg 1995).

I conducted the study in two forested 150-ha areas, one experimental and one control, separated by a buffer zone of $400-2000 \mathrm{~m}$. Adult male roe deer have been shown to be highly stable geographically (Bideau et al. 1993), and at Bogesund males occupy ranges of 20-50 ha (Cederlund et al. 1993, Wahlström and Kjellander 1995). I could thus be satisfactorily certain that males did not inhabit both areas, also supported by studies of radio-marked animals. The habitat in the two areas was similar, consisting of mature timber stands, thinned middle-aged forests, dense plantations, clearings with deciduous shrubs, and bogs. In both areas, the population was composed of marked as well as unmarked males (Table 1). The numbers and age composition of the latter were determined from observations made in April and constitute minimum estimates as some individuals may always remain concealed in forested habitats.

In the experimental area, 14 unmarked males were selectively culled by stalking in mid-August 1991. Shot males were aged by comparing their jaws with known age material (Cederlund et al. 1991). Eleven males were $\geq 3$ years old, 2 were subadults ( $2 \mathrm{yrs}$ ), and 1 was a yearling. A minimum of 14 males remained in the area after the shooting, 10 of which were radio-marked (Table 1) and 4 unmarked (1 adult, 1 subadult, and 2 yearlings). Hence, a minimum of 28 males had inhabited the experimental area before culling, which agrees with the estimated 26 in April (Table 1). An additional 8 males (5 adults and 3 subadults) were culled just outside $(150-850 \mathrm{~m})$ the experimental area. No culling was performed in the control area.

Rubs and scrapes were censused in 600 plots $\left(\right.$ each $40 \mathrm{~m}^{2}$ ), 300 in the control and the experimental area respectively, distributed every $50 \mathrm{~m}$ along north-south transects $100 \mathrm{~m}$ apart. I censused during 
May 13-23 in 1991 and May 11-21 in 1992, alternating from day to day between transects in the control and the experimental areas. I used chi-squared tests to compare frequencies of marking between years and areas, and to test if the number of males in the area (in April) differed the year before and and after culling.

\section{Results}

There was no difference in the number of males in the area in April 1991 and 1992 , ie before and after culling $\left(\chi^{2}=0.13, \mathrm{df}=1, p=0.720\right.$; Table 1$)$. The number of scrapes, however, decreased in both areas after the experimental removal of males (Table 2), but the decrease was significantly larger in the experimental area $(48 \%)$ than in the control area (16\%). Also the number of rubs decreased in both areas (32\% and $21 \%$ respectively), but the decrease did not differ significantly between the two areas (Table 2).

Table 1. Number of male roe deer of different age categories in the experimental- and control areas at Bogesund in April 1991 and 1992. The number of unmarked males constitute minimum estimates. a for unmarked males, 2-year-olds were not separated from adults.

\begin{tabular}{|c|c|c|c|c|c|c|c|c|}
\hline \multirow[b]{2}{*}{ Males } & \multicolumn{4}{|c|}{ Experimental area } & \multicolumn{4}{|c|}{ Control area } \\
\hline & Ad & $2 \mathrm{yrs}$ & $1 \mathrm{yr}$ & Total & Ad & $2 \mathrm{yrs}$ & $1 \mathrm{yr}$ & Total \\
\hline \multicolumn{9}{|l|}{1991} \\
\hline Marked & 3 & 3 & 4 & 10 & 4 & 1 & 4 & 9 \\
\hline Unmarked & 12 & a & 4 & 16 & 5 & $\mathrm{a}$ & 1 & 6 \\
\hline Total & 15 & 3 & 8 & 26 & 9 & 1 & 5 & 15 \\
\hline \multicolumn{9}{|l|}{1992} \\
\hline Marked & 5 & 3 & 1 & 9 & 3 & 3 & 2 & 8 \\
\hline Unmarked & 8 & $\mathrm{a}$ & 5 & 13 & 5 & $\mathrm{a}$ & 2 & 7 \\
\hline Total & 13 & 3 & 6 & 22 & 8 & 3 & 4 & 15 \\
\hline
\end{tabular}

Table 2. Number of scrapes and rubs censused in the experimental and control areas at Bogesund in May 1991 and 1992. Fourteen roe deer males (11 adults, 2 subadults, and 1 yearling) were culled in the experimental area in mid-August 1991.

\begin{tabular}{llrcccc}
\hline Marking & Area & 1991 & 1992 & $\begin{array}{c}\text { \% change } \\
\text { between years }\end{array}$ & $\chi^{2}$ & $p$ \\
\hline \multirow{2}{*}{ Scrapes } & Experimental & 100 & 52 & -48 & 4.03 & 0.045 \\
& Control & 80 & 67 & -16 & & 0.662 \\
\multirow{2}{*}{ Rubs } & Experimental & 37 & 25 & -32 & 0.19 & \\
& Control & 38 & 30 & -21 & & \\
\hline
\end{tabular}




\section{Discussion}

The reduced number of scrapes in the experimental area was in contrast to the increased number of scrapes observed by Davies and Davies (1968) after 4 males were culled in early May. Similarly, Cumming $(1966,1974)$ observed an increased number of rubs when males were removed within one territorial season. Davies and Davies (1968) do not mention the status of culled males, whereas Cumming (1966, 1974) knew he removed territorial males. In the present study, it is likely that shot males $\geq 3$ years old were territorial because all marked male roe deer in both Bogesund and the nearby Ekenäs area were territorial from the age of 3 years (Cederlund and Liberg 1995). The discrepancy between mine and Davies and Davies' (1968) and Cumming's (1966, 1974) results could be explained by the difference in timing of male removal.

When territorial males are removed early in the season, vacated territories are filled promptly (usually within $24 \mathrm{hrs}$, Loudon 1978). Newcomers have to recommence marking the area, in contrast to males that maintain an already established and marked territory. In addition, a replacement male might even be stimulated by the remaining marks of the predecessor, and therefore mark more intensively than a male who is the first occupant. When males, on the other hand, are removed late in the territorial season, vacated territories are usually not filled until the following spring (Loudon 1978). Cederlund et al. (1993), who used the same removal experiment to study effects on the spatial behaviour of roe deer at Bogesund, observed no movements into the experimental area during the months following the cull. The subsequent season, however, resident males were replaced, probably by immigrating males as no marked male moved into the experimental area (Cederlund et al. 1993).

The reduction in number of scrapes could be explained by a delay before territory establishment in the experimental area in 1992 compared with the previous year. It is possible that replacement males were not present in the area in late winter, unlike males reestablishing territories, but moved in later. If replacement males arrived even a few weeks later than normal, they would not participate in the same number of weeks of marking activity, resulting in a lower total number of markings in May. This could also explain why the reduction was larger for scrapes than for rubs, as scraping activity starts several weeks before rubbing (Johansson et al. 1995).

The overall tendency for fewer markings the second year could be an effect of that the population showed several signs of being close to carrying capacity in 1992 (Wahlström and Liberg 1995), with high juvenile mortality and low female fecundity. Reduced viability in males relative to females when subjected to high population density has been reported in eg red deer (Cervus elaphus; Clutton-Brock et al. 1982, 1985), and recent studies indicate that this applies also to roe deer (Gill 1994, Vincent et al. 1995). Hence, males in my population may have been in 
relatively poorer condition in 1992 than in 1991, which may have resulted in a reduced or delayed marking activity.

The results from this experiment suggest that removing adult male roe deer from an area between territorial seasons is not an effective way to reduce rubbing damage on young forest plantations, especially in dense populations with strong competition for territories, where all removed males are replaced the following season.

Acknowledgements: This study is part of a large ongoing investigation of roe deer demography and behaviour under the leadership of Drs O. Liberg and G. Cederlund. I thank Assi Domän AB for permission to work on their land, P. Kjellander for valuable information on culled males, and all hunters taking part in the shooting experiment. Further, I thank S. Nylin for statistical advice, and O. Liberg, K. Wahlström, P. Komers, M. Hewison, J.-M. Gaillard, and three anonymous referees for valuable comments on an earlier draft of the manuscript. Financial support was received through grants from the Swedish Hunters' Association and the Swedish Environmental Protection Board (both to O. Liberg).

\section{References}

Bideau E., Gerard J. F., Vincent J. P. and Maublanc M. L. 1993. Effects of age and sex on space occupation by European roe deer. Journal of Mammalogy 74: 745-751.

Bramley P. S. 1970. Territoriality and reproductive behaviour of roe deer. Journal of Reproduction and Fertility, suppl. 11: 43-70.

Cederlund G., Kjellander P. and Liberg O. 1993. Effects of buck hunting on spatial distribution among roe deer Capreolus capreolus L. Proceedings of the 21st Congress of the International Union of Game Biologists 21: 271-278.

Cederlund G., Kjellander P. and Stålfelt F. 1991. Age determination of roe deer by tooth wear and cementum layers - tests with known age material. Proceedings of the 20th Congress of the International Union of Game Biologists 20: 540-545.

Cederlund G. and Liberg O. 1995. [The roe deer: The game, ecology and hunting]. Almqvist och Wiksell Tryckeri, Uppsala: 1-301. [In Swedish]

Clutton-Brock T. H., Guinness F. E. and Albon S. D. 1982. Red deer: Behaviour and ecology of two sexes. The University of Chicago Press, Chicago: 1-378.

Clutton-Brock T. H., Major M. and Guinness F. E. 1985. Population regulation in male and female red deer. Journal of Animal Ecology 54: 831-846.

Cumming H. G. 1966. Behaviour and dispersion in roe deer (Capreolus capreolus). Ph D thesis, Aberdeen University, Aberdeen: 1-232.

Cumming H. G. 1974. Fraying behaviour and management of roe deer. [In: The behaviour of ungulates and its relation to management. V. Geist and F. Walther, eds]. International Union for Conservation of Nature and Natural Resources, Publications, New Series, 24: 813-829.

Davies H. S. and Davies M. W. 1968. Seasonal variations in roebuck scrapes. Deer 1: 164-165.

Gill R. M. A. 1994. The population dynamics of roe deer (Capreolus capreolus L.) in relation to forest habitat succession. Ph D thesis, The Open University, Milton Keynes: 1-191.

Johansson A., Liberg O. and Wahlström K. 1995. Temporal and physical characteristics of scraping and rubbing in roe deer (Capreolus capreolus). Journal of Mammalogy 76: 123-129.

Kurt F. 1991. Das Reh in der Kulturlandschaft. Sozialverhalten und Ökologie eines Anpassers. Verlag Paul Parey, Hamburg: 1-284.

Loudon A. S. I. 1978. The control of roe deer populations: a problem in forest management. Forestry 51: 73-83.

Raesfeld F. von, Neuhaus A. H. and Schaich K. 1985. Das Rehwild. 9th ed. Verlag Paul Parey, Hamburg: 1-450. 
Sempéré A., Garreau J.-J. and Boissin J. 1980. Variations saisonnières de l'activité de marquage territorial et de la testostéronémie chez le Chevreuil mâle adulte (Capreolus capreolus L.). Compte Rendus de l'Académie des Sciences, Série D 290: 803-806.

Strandgaard H. 1972. The roe deer (Capreolus capreolus) population at Kalø and the factors regulating its size. Danish Review of Game Biology 7: 1-205.

Vincent J. P., Bideau E., Hewison A. J. M. and Angibault J. M. 1995. The influence of increasing density on body weight, kid production, home range and winter grouping in roe deer (Capreolus capreolus). Journal of Zoology, London 236: 371-382.

Wahlström L. K. and Kjellander P. 1995. Ideal free distribution and natal dispersal in female roe deer. Oecologia 103: 302-308.

Wahlström L. K. and Liberg O. 1995. Patterns of dispersal and seasonal migration in roe deer (Capreolus capreolus). Journal of Zoology, London 235: 455-467.

Received 30 June 1998, accepted 15 May 1999. 